\title{
2011 Honda CR-Z 4466 - Hybrid Electric Vehicle Battery Test Results
}

\author{
Tyler Gray \\ Matthew Shirk \\ Jeffrey Wishart \\ September 2014
}

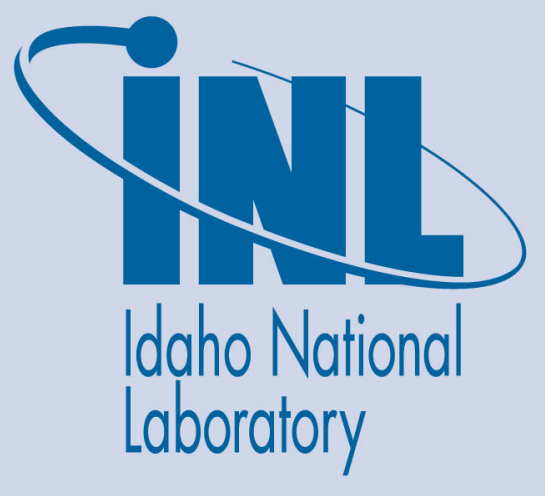

The INL is a U.S. Department of Energy National Laboratory operated by Battelle Energy Alliance 
INL/EXT-14-32474

\title{
2011 Honda CR-Z 4466 - Hybrid Electric Vehicle Battery Test Results
}

\author{
Tyler Gray \\ Matthew Shirk \\ Jeffery Wishart
}

September 2014

\author{
Idaho National Laboratory \\ Idaho Falls, Idaho 83415
}

http://www.inl.gov

Prepared for the

U.S. Department of Energy

Assistant Secretary for Energy Efficiency/Renewable Energy

Under DOE Idaho Operations Office

Contract DE-AC07-05ID14517 


\title{
2011 Honda CR-Z 4466 - Hybrid Electric Vehicle Battery Test Results
}

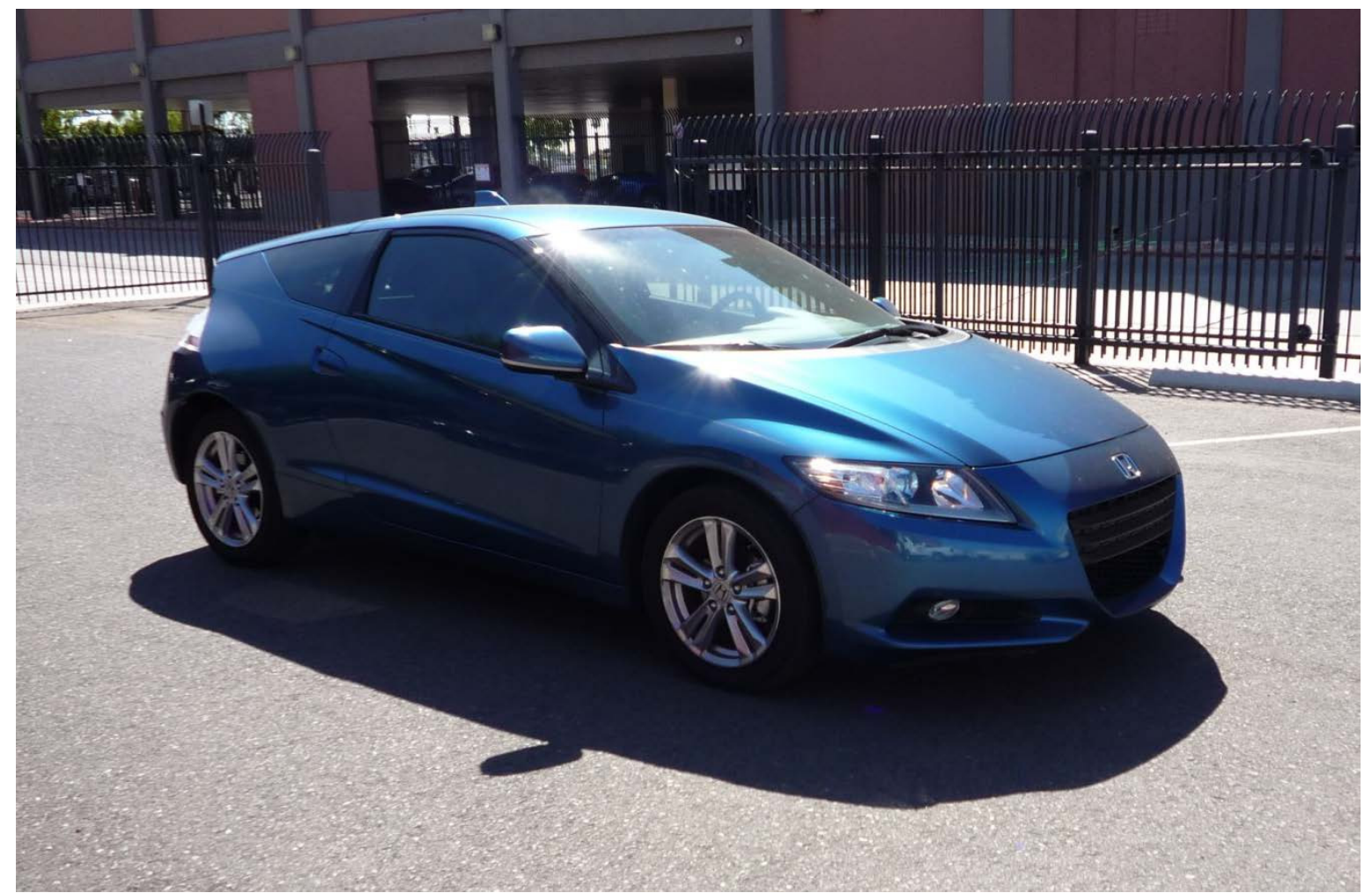

\author{
Tyler Gray \\ Matthew Shirk \\ Jeffrey Wishart
}

September 2014 


\section{DISCLAIMER}

This information was prepared as an account of work sponsored by an agency of the U.S. Government. Neither the U.S. Government nor any agency thereof, nor any of their employees, makes any warranty, expressed or implied, or assumes any legal liability or responsibility for the accuracy, completeness, or usefulness, of any information, apparatus, product, or process disclosed, or represents that its use would not infringe privately owned rights. References herein to any specific commercial product, process, or service by trade name, trade mark, manufacturer, or otherwise, does not necessarily constitute or imply its endorsement, recommendation, or favoring by the U.S. Government or any agency thereof. The views and opinions of authors expressed herein do not necessarily state or reflect those of the U.S. Government or any agency thereof. 


\title{
2011 Honda CR-Z 4466 - Hybrid Electric Vehicle Battery Test Results
}

\author{
Tyler Gray ${ }^{1}$ \\ Jeffrey Wishart ${ }^{1}$ \\ Matthew Shirk ${ }^{2}$
}

September 2014

Prepared for the

U.S. Department of Energy

Assistant Secretary for Energy Efficiency and Renewable Energy

Under DOE Idaho Operations Office

Contract DE-AC07-05ID14517

1. Intertek Testing Services NA

2. Idaho National Laboratory 


\begin{abstract}
The U.S. Department of Energy's Advanced Vehicle Testing Activity Program consists of vehicle, battery, and infrastructure testing on advanced technology related to transportation. The activity includes tests on hybrid electric vehicles, including testing traction batteries when both the vehicles and batteries are new and at the conclusion of 160,000 miles of on-road fleet testing. This report documents battery testing performed for the 2011 Honda CR-Z (VIN JHMZF1C67BS004466). Battery testing was performed by Intertek Testing Services NA. The Idaho National Laboratory and Intertek collaborate on the Advanced Vehicle Testing Activity for the Vehicle Technologies Office of the U.S. Department of Energy.
\end{abstract}




\section{CONTENTS}

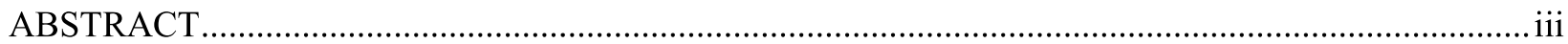

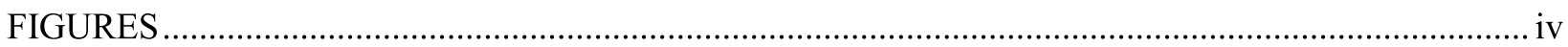

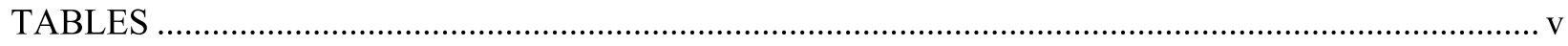

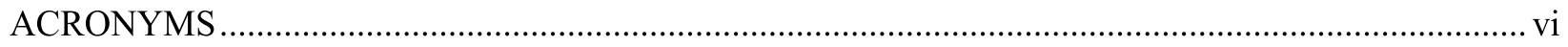

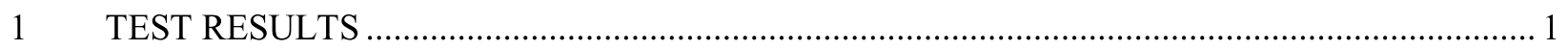

1.1 Static Capacity Test Results .......................................................................................... 1

1.2 Hybrid Pulse Power Characterization Test Results............................................................ 1

1.3 Acceleration Test Results........................................................................................... 6

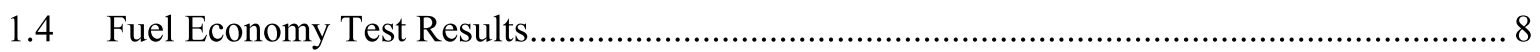

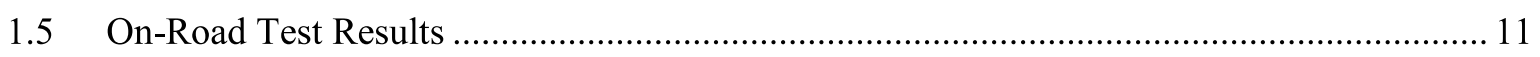

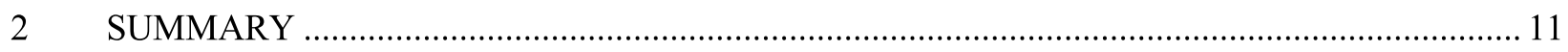

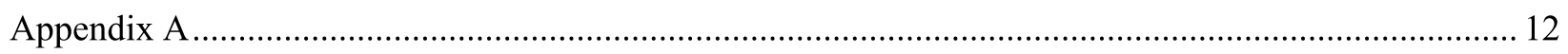

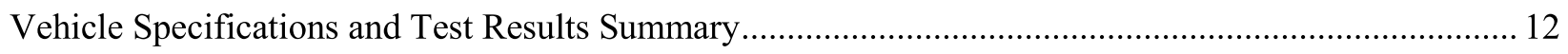

\section{FIGURES}

Figure 1. Voltage versus energy discharged during the static capacity test.............................................................2

Figure 2. Ten-second charge pulse resistance versus energy discharged ............................................................... 3

Figure 3. Ten-second charge pulse power capability versus energy discharged............................................................

Figure 4. Ten-second discharge pulse resistance versus energy discharged ..............................................................4

Figure 5. Ten-second discharge pulse power capability versus energy discharged ......................................................

Figure 6. Discharge and charge power capabilities versus energy discharged .......................................................5

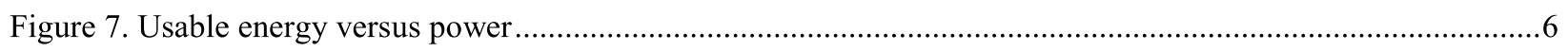

Figure 8. Battery power versus time from acceleration testing ...............................................................................

Figure 9. Battery voltage versus time from acceleration testing ..........................................................................

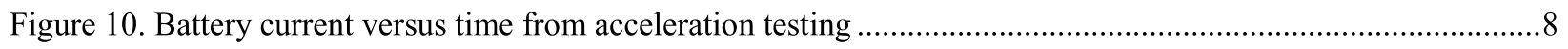

Figure 11. Battery pack current, voltage, and vehicle speed for UDDS cycle.......................................................

Figure 12. Battery pack current, voltage, and vehicle speed for two back-to-back HWFET cycles..........................10

Figure 13. Battery pack current, voltage, and vehicle speed for a UDDS cycle with the elevated ambient temperature

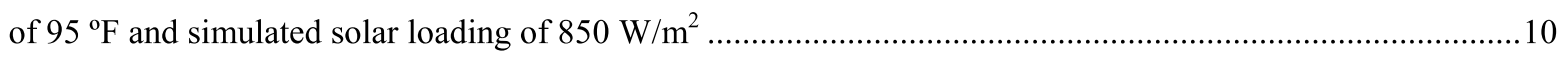

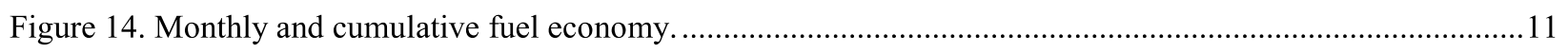




\section{TABLES}

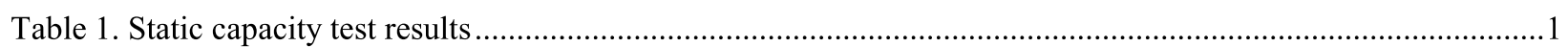

Table 2. Hybrid Pulse Power Characterization test results..............................................................................

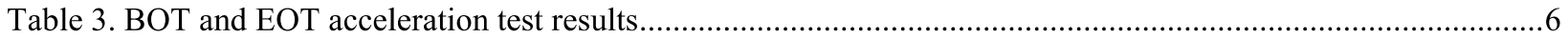

Table 4. Battery performance results from the dynamometer drive-cycle testing .................................................. 8 


\section{ACRONYMS}

$\begin{array}{ll}\text { Ah } & \text { amp-hour } \\ \text { BOT } & \text { beginning of test } \\ \text { DOE } & \text { Department of Energy } \\ \text { EOT } & \text { end of test } \\ \text { HEV } & \text { hybrid electric vehicle } \\ \text { HPPC } & \text { Hybrid Pulse Power Characterization } \\ \text { HWFET } & \text { Highway Fuel Economy Test } \\ \text { kW } & \text { kilowatt } \\ \text { mi } & \text { mile } \\ \text { MPH } & \text { miles per hour } \\ \Omega & \text { ohm } \\ \text { s } & \text { second } \\ \text { UDDS } & \text { Urban Dynamometer Drive Schedule } \\ \text { US06 } & \text { high speed/high load drive-cycle dynamometer test } \\ \text { V } & \text { volt } \\ \text { VDC } & \text { volt direct current } \\ \text { VIN } & \text { vehicle identification number } \\ \text { Vpc } & \text { volt per cell } \\ \text { Wh } & \text { watt-hour }\end{array}$




\section{Honda CR-Z 4466 - Hybrid Electric Vehicle Battery Test Results}

\section{TEST RESULTS}

The U.S. Department of Energy's (DOE) Advanced Vehicle Testing Activity program consists of vehicle, battery, and infrastructure testing on advanced technology related to transportation. The activity includes tests on hybrid electric vehicles (HEV), including testing traction batteries when both the vehicles and batteries are new (i.e., beginning-of-test or BOT) and at the conclusion of 160,000 miles of on-road fleet testing (i.e., end-of-test or EOT). This report provides test results for BOT and EOT battery testing conducted on a 2011 Honda CR-Z HEV, number 4466 (full VIN: JHMZF1C67BS004466), from both laboratory and on-road test configurations. The battery laboratory test results include those from the static capacity test and the Hybrid Pulse Power Characterization (HPPC) test. ${ }^{1}$ Vehicle test results include those from acceleration testing and fuel economy testing. ${ }^{2}$

The battery and vehicle testing was performed by Intertek Testing Services NA. The Idaho National Laboratory and Intertek collaborate on the Advanced Vehicle Testing Activity for the Vehicle Technologies Program of DOE.

\subsection{Static Capacity Test Results}

Results from the laboratory BOT and EOT static capacity tests are provided in Table 1.

Table 1. Static capacity test results

\begin{tabular}{lccccc}
\hline & Test Date & $\begin{array}{c}\text { Odometer } \\
(\mathbf{m i})\end{array}$ & $\begin{array}{c}\text { Rated Capacity } \\
(\mathbf{A h})\end{array}$ & $\begin{array}{c}\text { Measured } \\
\text { Capacity (Ah) }\end{array}$ & $\begin{array}{c}\text { Measured } \\
\text { Energy (Wh) }\end{array}$ \\
\hline BOT & Dec 30, 2010 & 3,995 & 5.75 & 5.79 & 600 \\
EOT & Jan 16, 2014 & 160,266 & 5.75 & 5.11 & 530 \\
Difference & - & 156,271 & - & $0.68(12 \%)$ & $70(12 \%)$ \\
\hline
\end{tabular}

Figure 1 shows battery voltage versus energy discharged. This graph illustrates voltage values during constant-current discharge versus cumulative energy discharged from the battery at a $\mathrm{C} / 1$ constant-current discharge rate at BOT and EOT.

\subsection{Hybrid Pulse Power Characterization Test Results}

The HPPC test results are summarized in Table 2. Figure 2 and Figure 4 illustrate the charge and discharge pulse resistance graphs of the battery, respectively. The internal resistance is depicted over a range of 10 to $90 \%$ depth of discharge, which is represented by the amount of energy discharged at each interval. Each curve represents the specified HPPC BOT or EOT resistance at the end of the 10-second pulse interval.

Figure 3 and Figure 5 illustrate the charge and discharge pulse power capability graphs of the battery, respectively. The power capability is depicted over a range of 10 to $90 \%$ depth of discharge, which is represented by the amount of energy discharged at each interval. Each curve represents the calculated

1 Static capacity and HPPC test procedures are based on the FreedomCAR Battery Test Manual for Power-Assist Hybrid Electric Vehicles, DOE/ID-11069, October 2003, Procedures 3.2 and 3.3, respectively. The measured capacity at BOT testing was used to determine the magnitude of current during all HPPC tests.

2 Acceleration testing and fuel economy testing procedures were performed in accordance with the Advanced Vehicle Testing Activity HEV America test procedures ETA-HTP02 and ETA-HTP03, respectively. 
HPPC BOT or EOT available power capability at the end of the 10 -second pulse interval at the cell voltage limits.

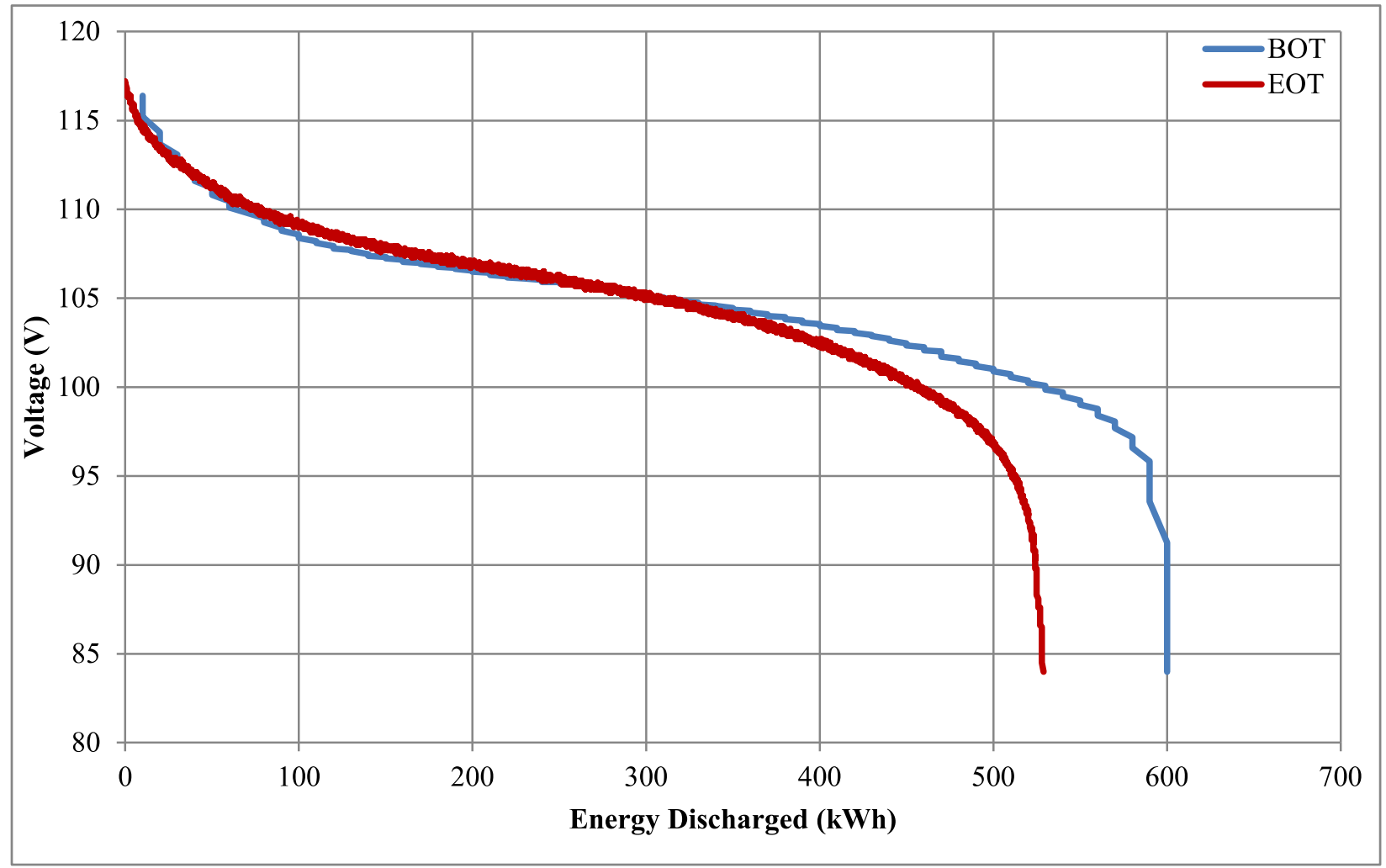

Figure 1. Voltage versus energy discharged during the static capacity test

Table 2. Hybrid Pulse Power Characterization test results

\begin{tabular}{lcccc}
\hline & $\begin{array}{c}\text { 10 s Discharge } \\
\text { Power Capability } \\
\text { at 50\% DOD } \\
(\mathbf{k W})\end{array}$ & $\begin{array}{c}\text { 10 s Charge } \\
\text { Power Capability } \\
\text { at 50\% DOD } \\
(\mathbf{k W})\end{array}$ & $\begin{array}{c}\text { Maximum } \\
\text { Cell Voltage } \\
(\mathbf{V})\end{array}$ & $\begin{array}{c}\text { Minimum } \\
\text { Cell Voltage } \\
(\mathbf{V})\end{array}$ \\
\hline BOT & 8.74 & 8.81 & 1.5 & 1.0 \\
EOT & 8.42 & 7.87 & 1.5 & 1.0 \\
Difference & $0.32(3.7 \%)$ & $0.94(11 \%)$ & $0(0 \%)$ & $0(0 \%)$ \\
\hline
\end{tabular}




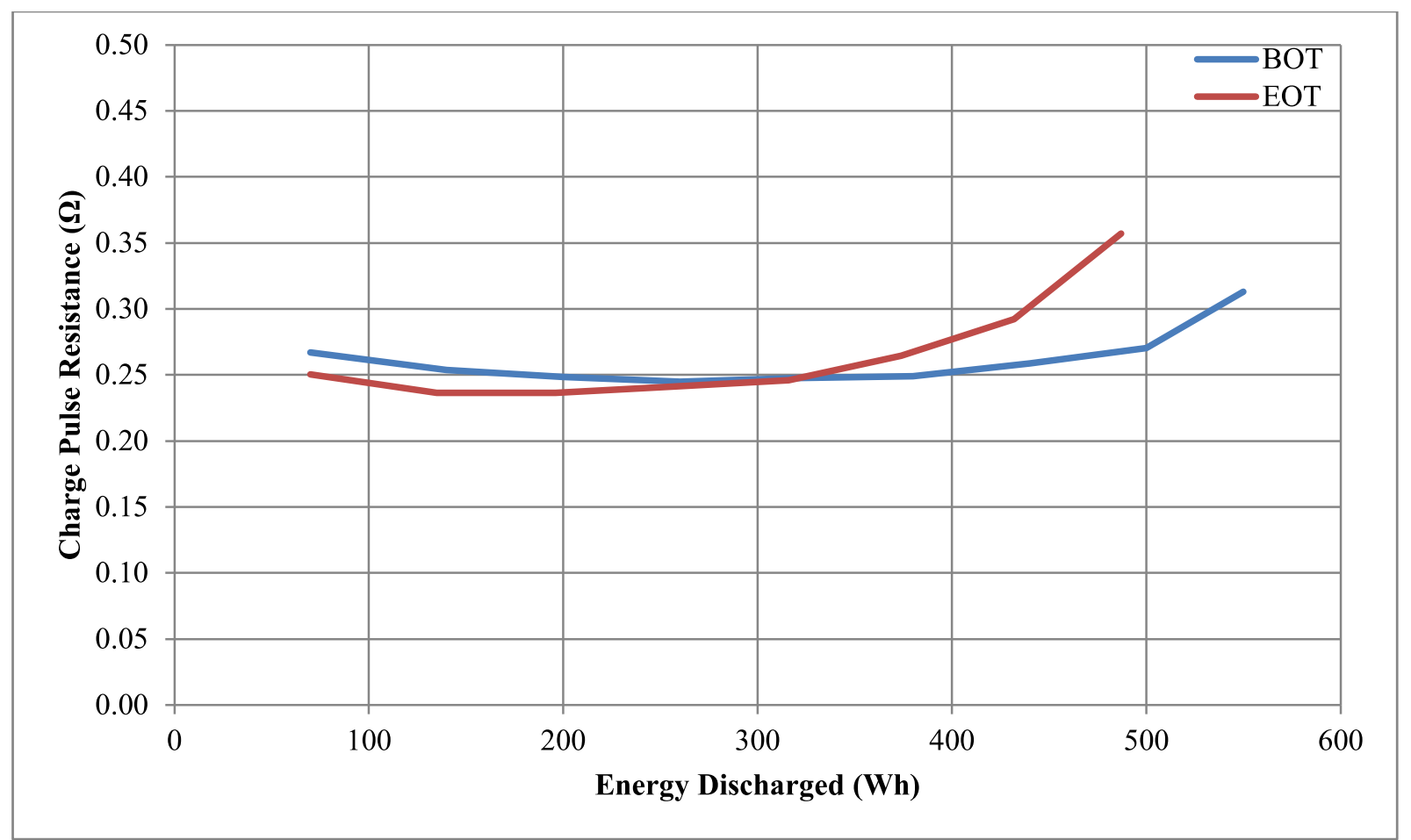

Figure 2. Ten-second charge pulse resistance versus energy discharged

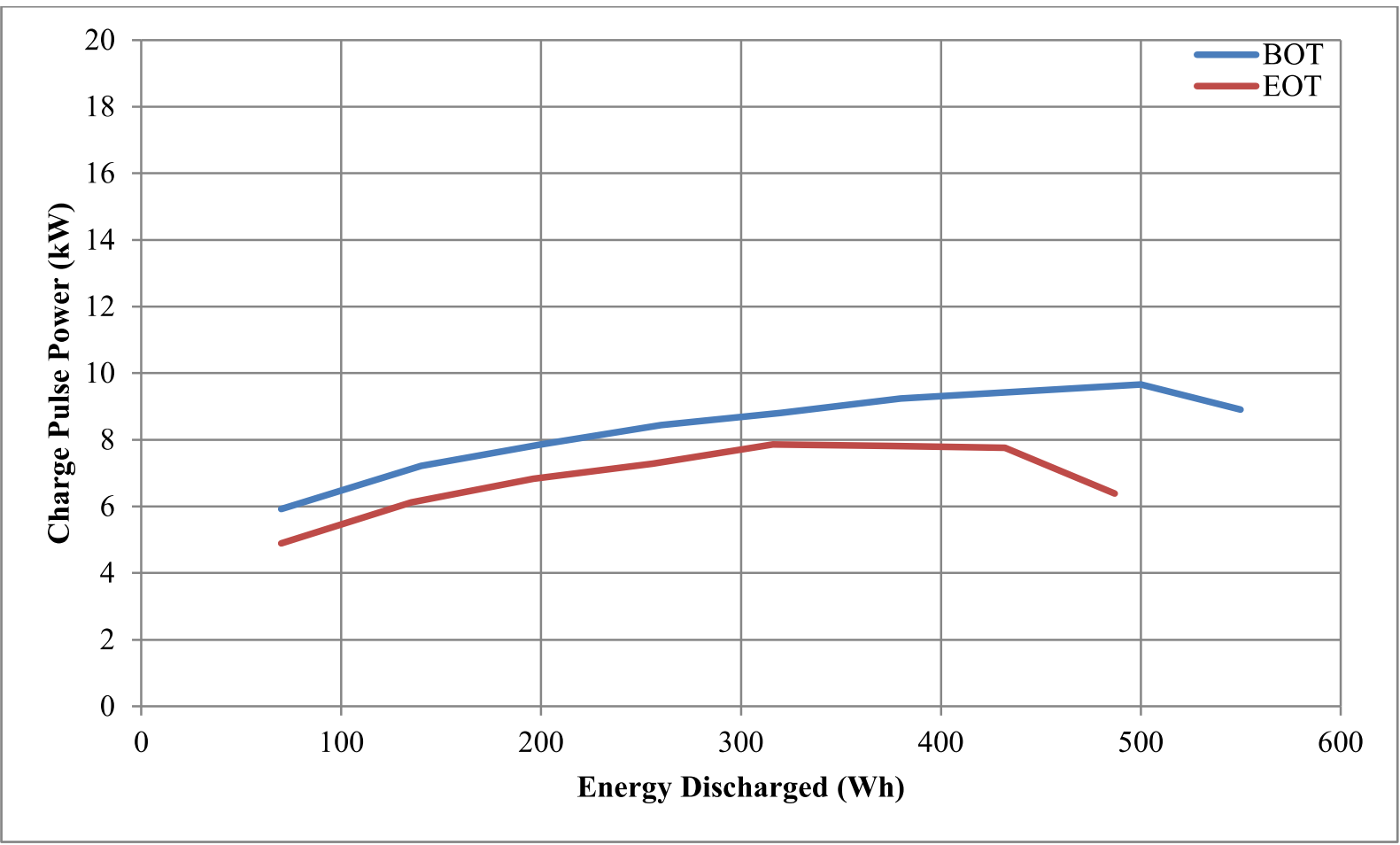

Figure 3. Ten-second charge pulse power capability versus energy discharged 


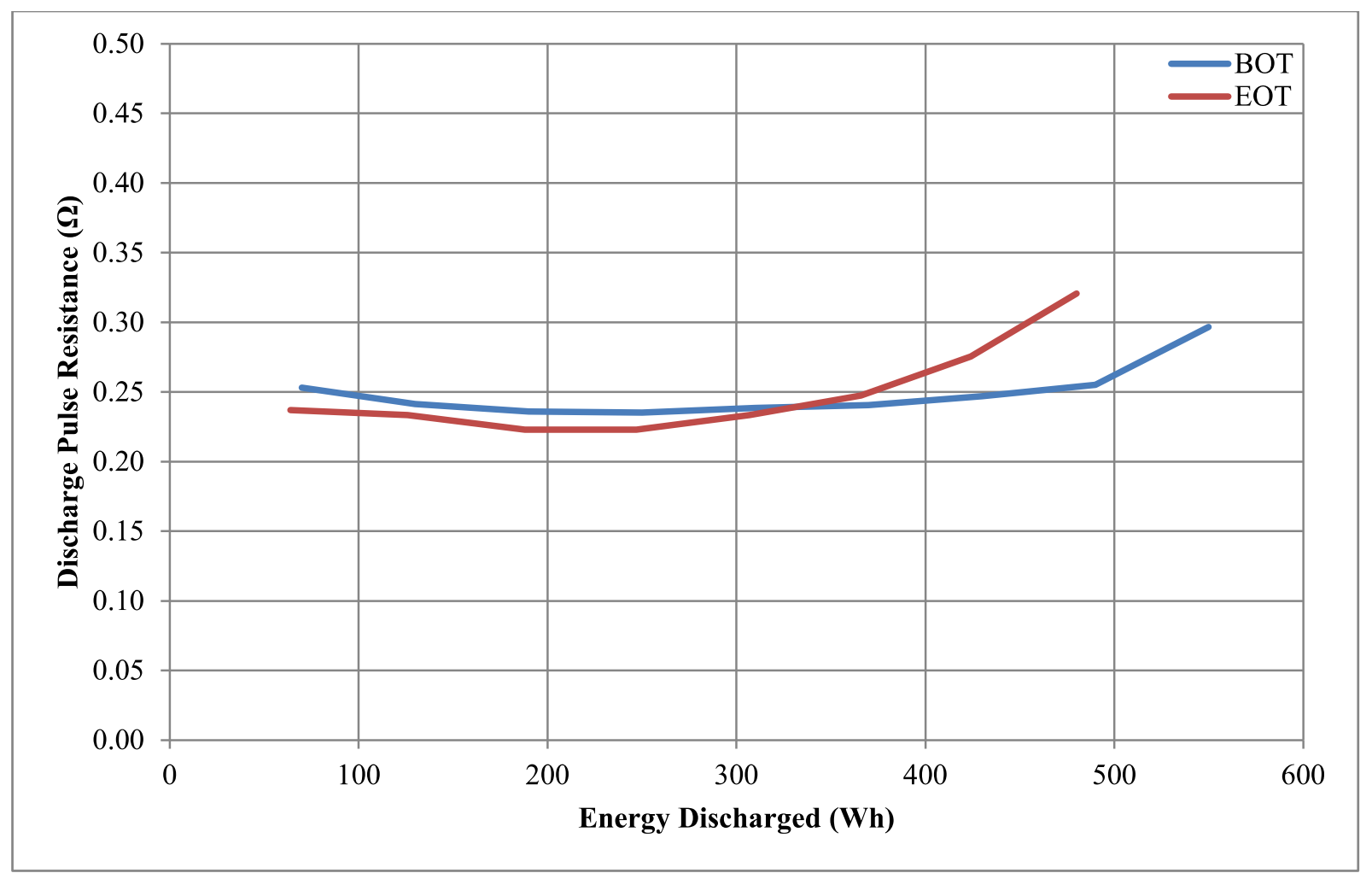

Figure 4. Ten-second discharge pulse resistance versus energy discharged

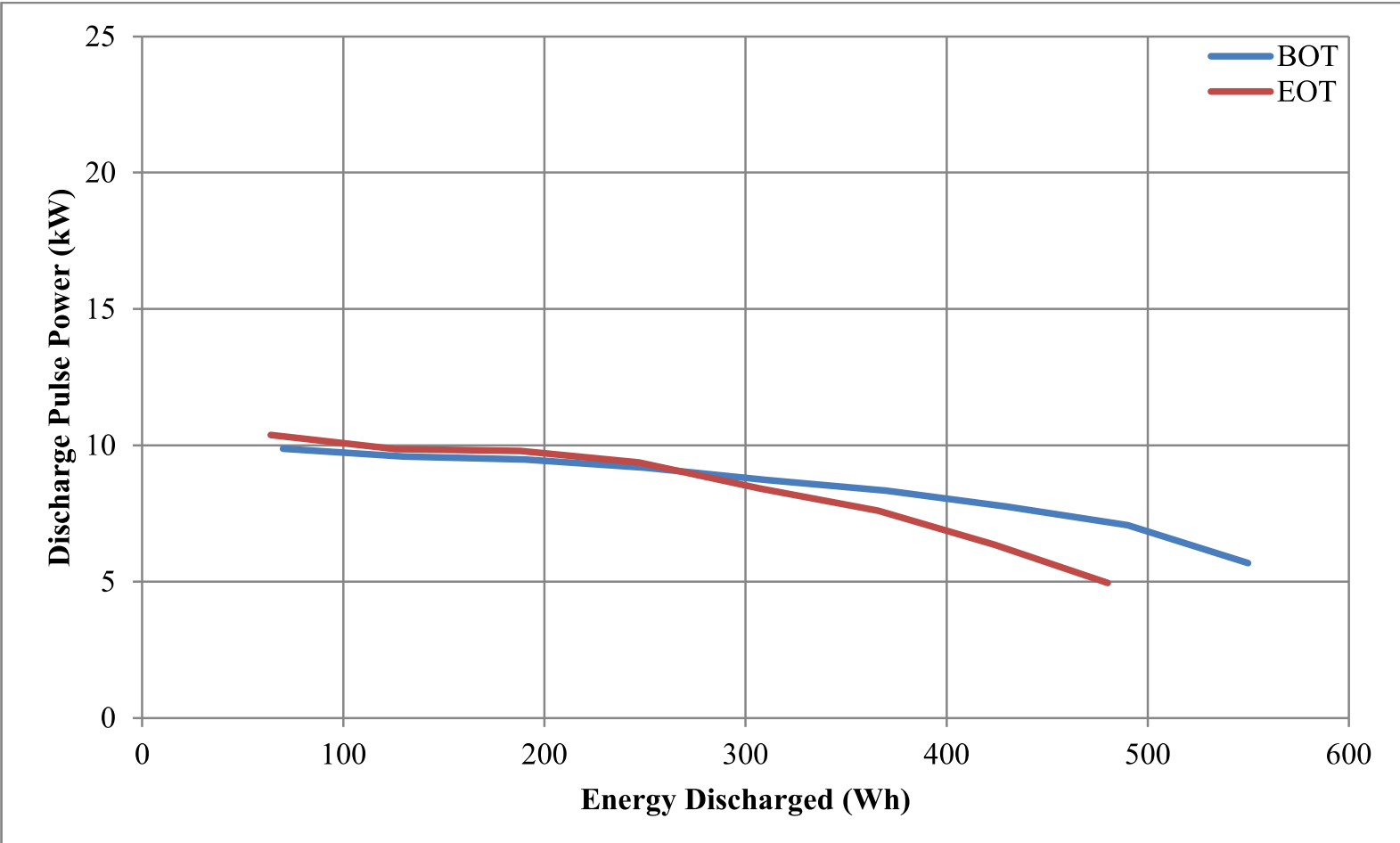

Figure 5. Ten-second discharge pulse power capability versus energy discharged 
Figure 6 is a plot of the BOT and EOT HPPC 10-second pulse charge and discharge power capability values of the battery as a function of energy discharged. The graph shows the power values over the range of energy discharged, with discharge power on the primary (left) axis and charge power on the secondary (right) axis. The DOE targets for a hybrid power-assist battery for discharge power (i.e., $25 \mathrm{~kW}$ ) and charge regenerative power (i.e., $20 \mathrm{~kW}$ ) are included for comparative purposes. Neither the BOT or EOT pulse power values meet the DOE power targets (denoted by the black, horizontal dashed line in the figure) for any battery energy discharged range.

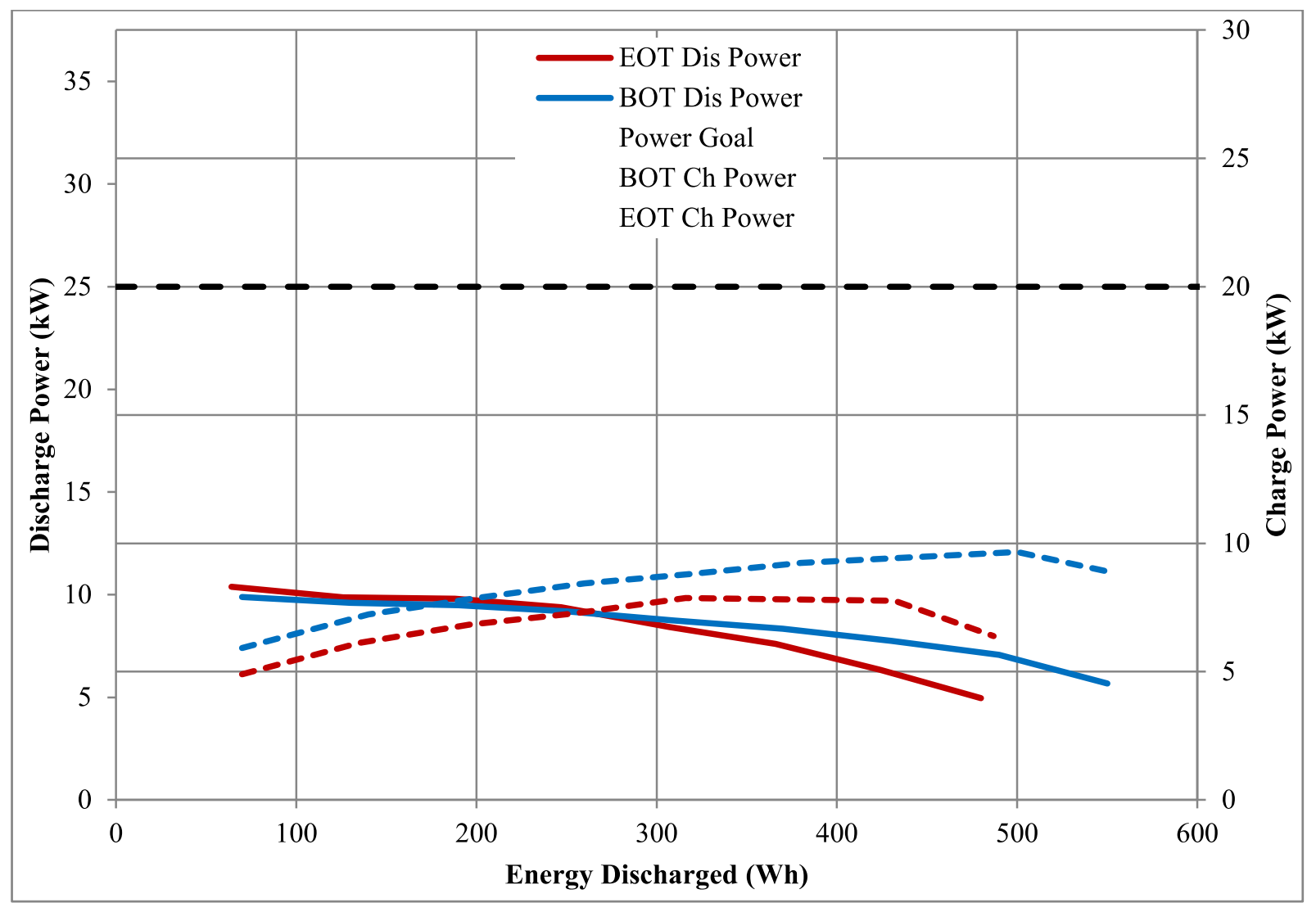

Figure 6. Discharge and charge power capabilities versus energy discharged

Figure 7 is a plot of the BOT and EOT usable energy as a function of battery power. The $\mathrm{x}$-axis indicates a desired discharge power level and the y-axis indicates the usable energy at that power. The dashed horizontal line shows the DOE minimum power-assist HEV energy target of $300 \mathrm{Wh}$. The dashed vertical line shows the DOE minimum power-assist HEV discharge power target of $25 \mathrm{~kW}$. No portion of the BOT useable energy curve of the CR-Z battery falls above and to the right of the intersection of DOE energy and power targets. The maximum power that can be delivered while meeting the DOE energy target is $7.4 \mathrm{~kW}$ at $300 \mathrm{Wh}$. No energy can be delivered while meeting the DOE power target of $25 \mathrm{~kW}$. This indicates that at the time of BOT testing, the CR-Z battery performance was below DOE targets. No portion of the EOT useable energy curve of the battery falls above and to the right of the intersection of the DOE energy and power targets. The maximum power that can be delivered while meeting the DOE energy target is $6.1 \mathrm{~kW}$ at $300 \mathrm{Wh}$. No energy can be delivered while meeting the DOE power target of $25 \mathrm{~kW}$. This indicates that at the time of EOT testing, the CR-Z battery performance was below DOE targets. 


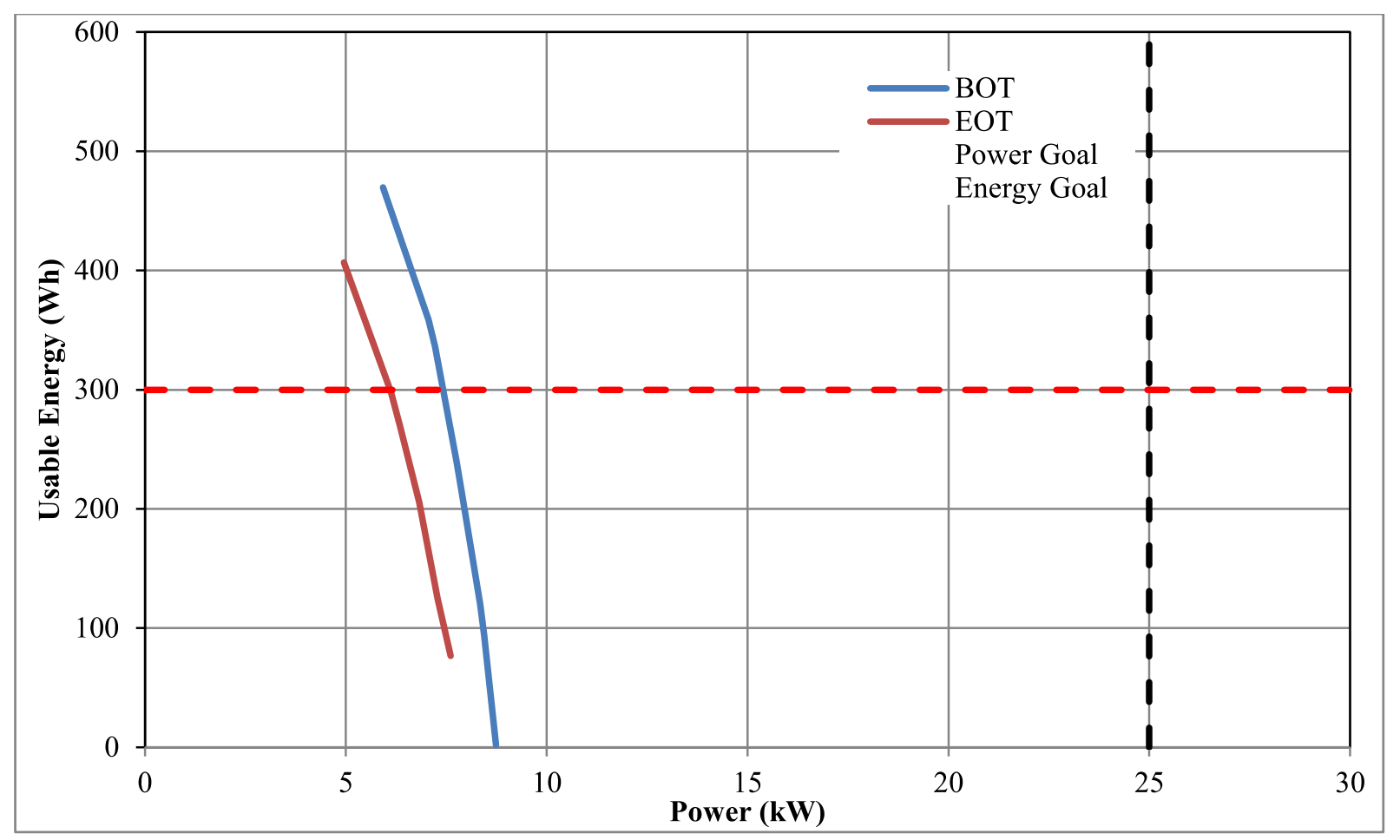

Figure 7. Usable energy versus power

\subsection{Acceleration Test Results}

BOT and EOT results from vehicle on-track acceleration tests are summarized in Table 3.

Table 3. BOT and EOT acceleration test results ${ }^{3}$

\begin{tabular}{lcccccc}
\hline & $\begin{array}{c}\text { Average } \\
\text { Discharge } \\
\text { Power Over } \\
\text { 10 s (kW) }\end{array}$ & $\begin{array}{c}\text { Energy } \\
\text { Discharged } \\
\text { Over Test } \\
(\mathbf{W h})\end{array}$ & $\begin{array}{c}\text { Capacity } \\
\text { Discharged } \\
\text { Over Test } \\
(\mathbf{A h})\end{array}$ & $\begin{array}{c}\text { Peak Power } \\
\text { Over Test } \\
(\mathbf{k W})\end{array}$ & $\begin{array}{c}\text { Minimum } \\
\text { Discharge } \\
\text { Pack } \\
\text { Voltage (V) }\end{array}$ & $\begin{array}{c}\text { Minimum } \\
\text { Discharge } \\
\text { Cell Voltage } \\
\text { (V) }\end{array}$ \\
\hline BOT & 8.53 & 107.1 & 1.11 & 11.9 & 87.2 & 1.04 \\
\hline EOT & 8.21 & 87.2 & 0.91 & 10.5 & 91.8 & 1.09 \\
\hline
\end{tabular}

Figure 8 shows battery power versus time during the one-mile acceleration test at BOT and EOT. This graph is the basis for power calculations over specified time or distance intervals and the cumulative discharged energy capacity during the duration of the test. At the beginning of the acceleration test, the power quickly increases from approximately $0 \mathrm{~kW}$ to a peak value. The power then remains relatively constant based on battery or vehicle system dynamics (such as gear shifting), which may include battery control logic cause the power to reduce exponentially.

Figure 9 shows the battery voltage versus time during the 1-mile acceleration test at BOT and EOT. Values are analyzed to determine the minimum voltage allowed by the battery control module, if possible. Although the test may not yield a definitive minimum voltage value, it can provide an approximation for comparison to the HPPC analysis results. This graph also shows the impact of power electronics and a battery controller on the voltage response.

3 Because of the speed restrictions at the test track where acceleration tests were performed, the vehicle could not be accelerated for 1 full mile. 


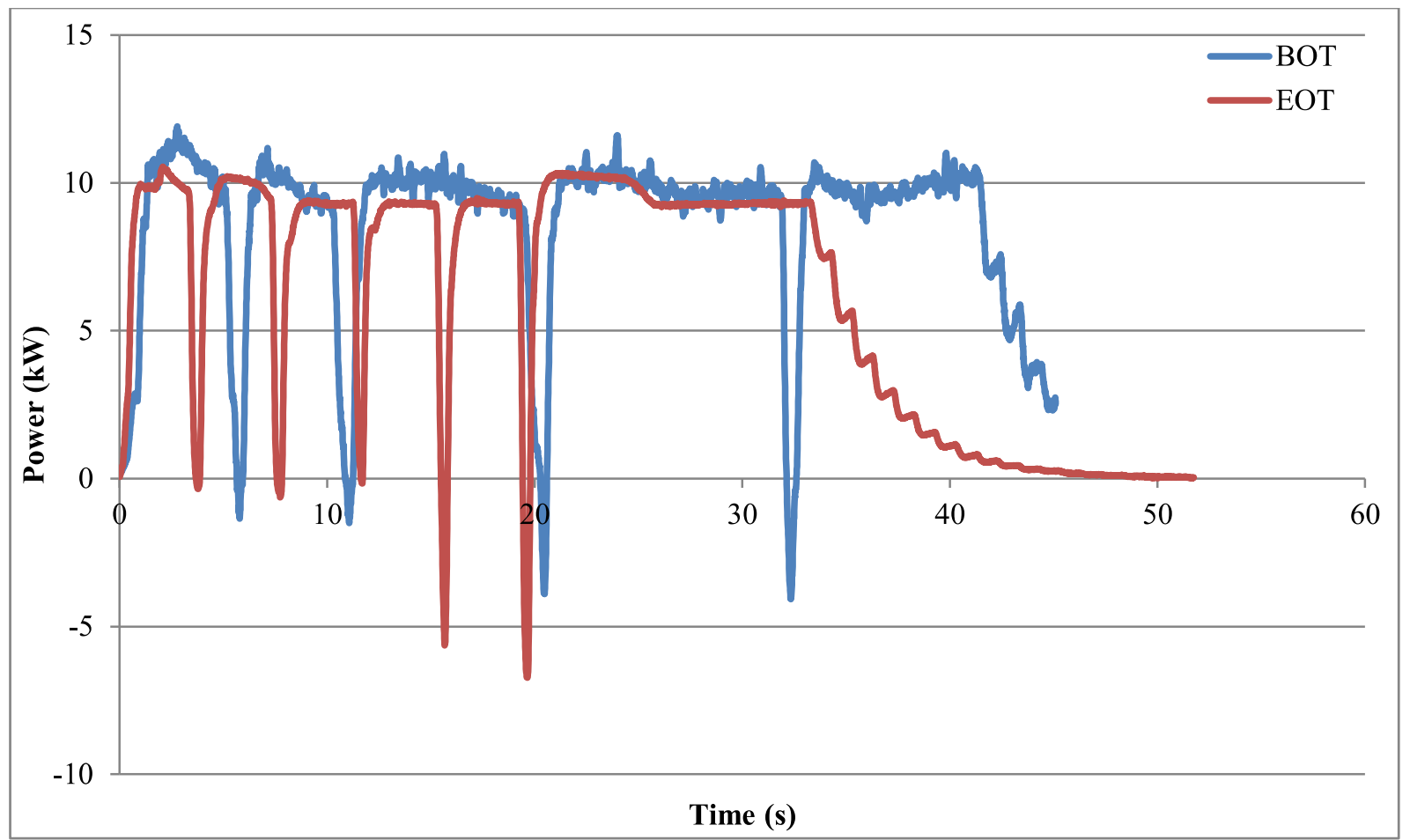

Figure 8 . Battery power versus time from acceleration testing

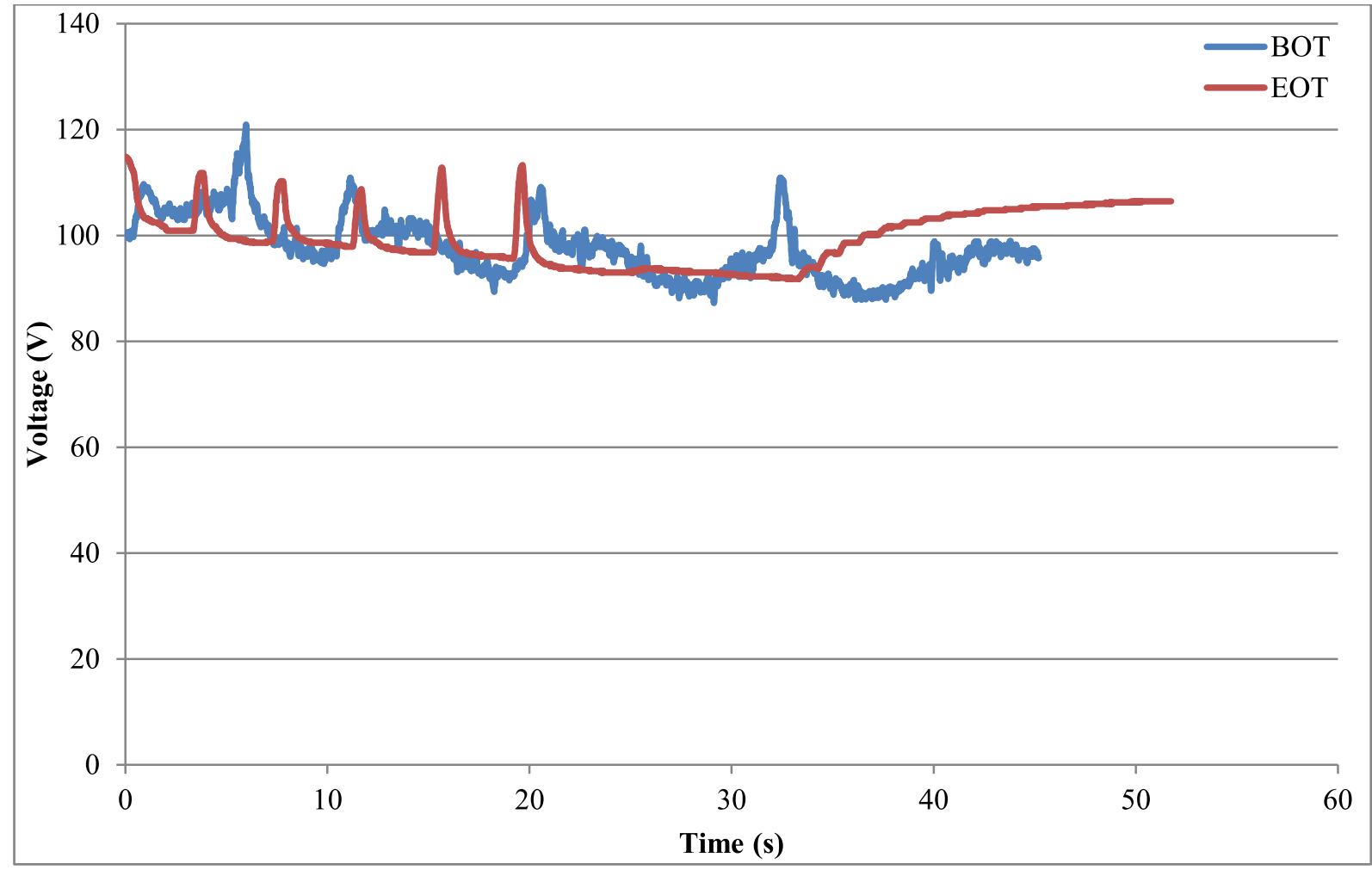

Figure 9. Battery voltage versus time from acceleration testing 
Figure 10 shows battery current versus time during the 1-mile acceleration test at BOT and EOT. This graph also is the basis for determining the discharged capacity during the test run. Lastly, the power results in Figure 8 can be obtained by simply multiplying the voltage values from Figure 9 by the current values in Figure 10.

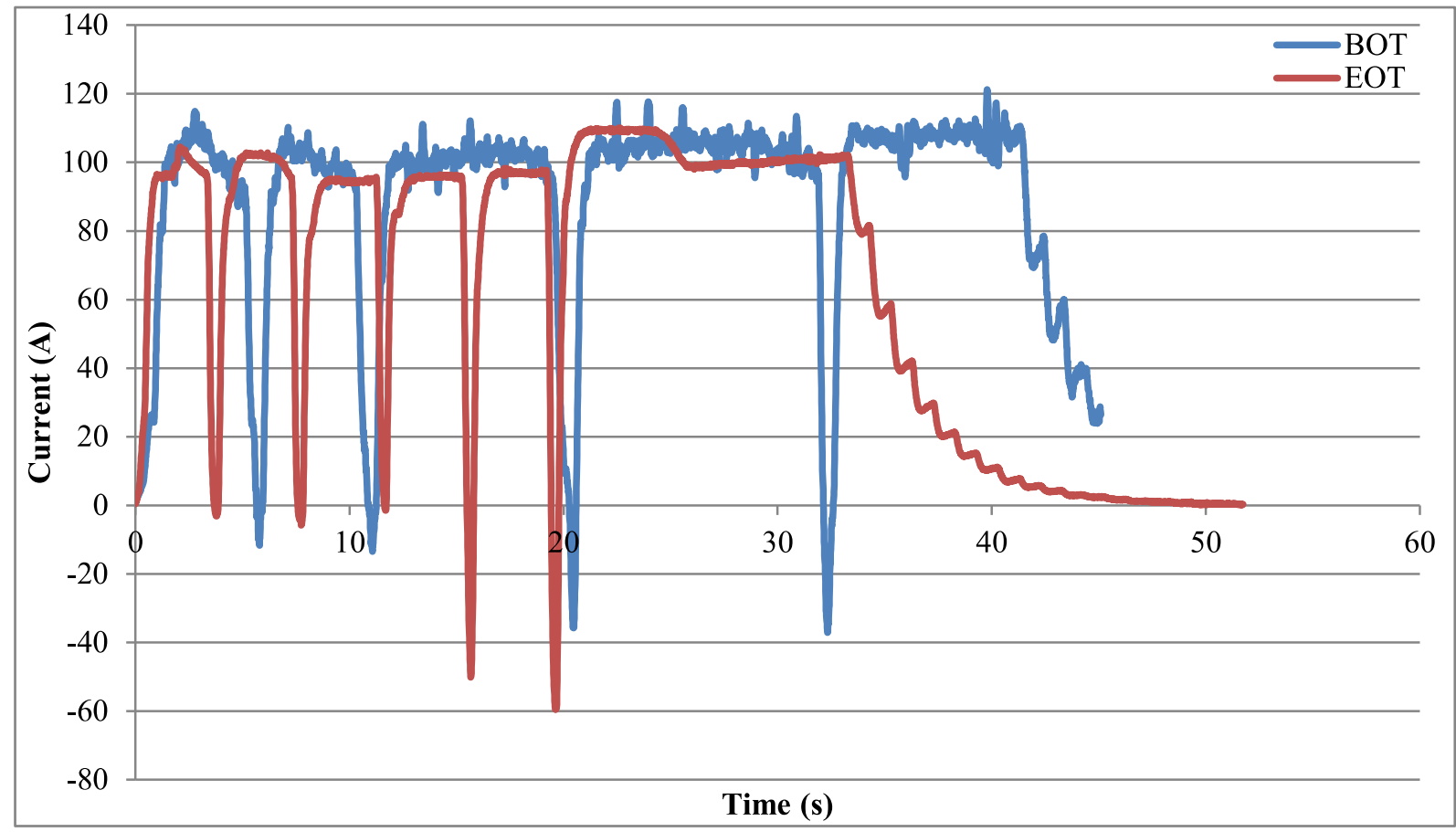

Figure 10. Battery current versus time from acceleration testing

\subsection{Fuel Economy Test Results}

Battery performance results were obtained from testing conducted on a chassis dynamometer with Honda CR-Z 4932 at Argonne National Laboratory. The Urban Dynamometer Drive Schedule (UDDS), Highway Fuel Economy Test (HWFET), and a UDDS ${ }^{4}$ at an elevated temperature of $95^{\circ} \mathrm{F}$ with a simulated solar load of $850 \mathrm{~W} / \mathrm{m}^{2}$ were conducted at BOT. Battery performance results from the dynamometer drive cycle testing are summarized in Table 4.

Table 4. Battery performance results from the dynamometer drive-cycle testing

\begin{tabular}{|l|c|c|c|}
\hline & UDDS & HWFET & UDDS (at $\mathbf{~ 9 5}^{\mathbf{0}} \mathbf{F}+\mathbf{8 5 0} \mathbf{~ W} / \mathbf{m}^{\mathbf{2}}$ ) \\
\hline Peak Discharge Power (kW): & 10.1 & 9.43 & 9.08 \\
\hline Peak Charge Power (kW): & 6.23 & 5.76 & 7.86 \\
\hline Measured Discharge Energy (kWh): & 0.15 & 0.10 & 0.23 \\
\hline Measured Charge Energy (kWh): & 0.13 & 0.12 & 0.20 \\
\hline Measured Discharge Capacity (Ah): & 1.23 & 0.88 & 1.90 \\
\hline Measured Charge Capacity (Ah): & 1.15 & 1.09 & 1.78 \\
\hline Minimum Pack Voltage (V): & 127.5 & 125.7 & 126.5 \\
\hline Maximum Pack Voltage (V): & 103.5 & 104.9 & 96.7 \\
\hline Discharge/Charge Capacity Ratio: & 1.07 & 0.81 & 1.07 \\
\hline \hline
\end{tabular}

4 UDDS and HWFET drive cycles were performed as defined by the Environmental Protection Agency. The definitions of each cycle can be found at http://www.epa.gov/nvfel/testing/dynamometer.htm\#vehcycles 
Figures 11,12 , and 13 show how the hybrid battery pack is utilized in comparison to vehicle speed for the UDDS, HWFET, and UDDS at the elevated temperature and simulated solar load cycles. For each, the battery pack utilization is directly correlated to the driving style being performed in the drivecycle. During the UDDS cycle, which simulates city driving with mildly aggressive accelerations and braking, the battery pack frequently transitions between discharging and charging. During the HWFET cycle, which simulates highway driving where the vehicle is in nearly continuous motion, the battery pack is cycled less frequently. During the UDDS at the elevated temperature of $95^{\circ} \mathrm{F}$ and simulated solar load of $850 \mathrm{~W} / \mathrm{m}^{2}$, the battery pack performs the same as the original UDDS cycle.

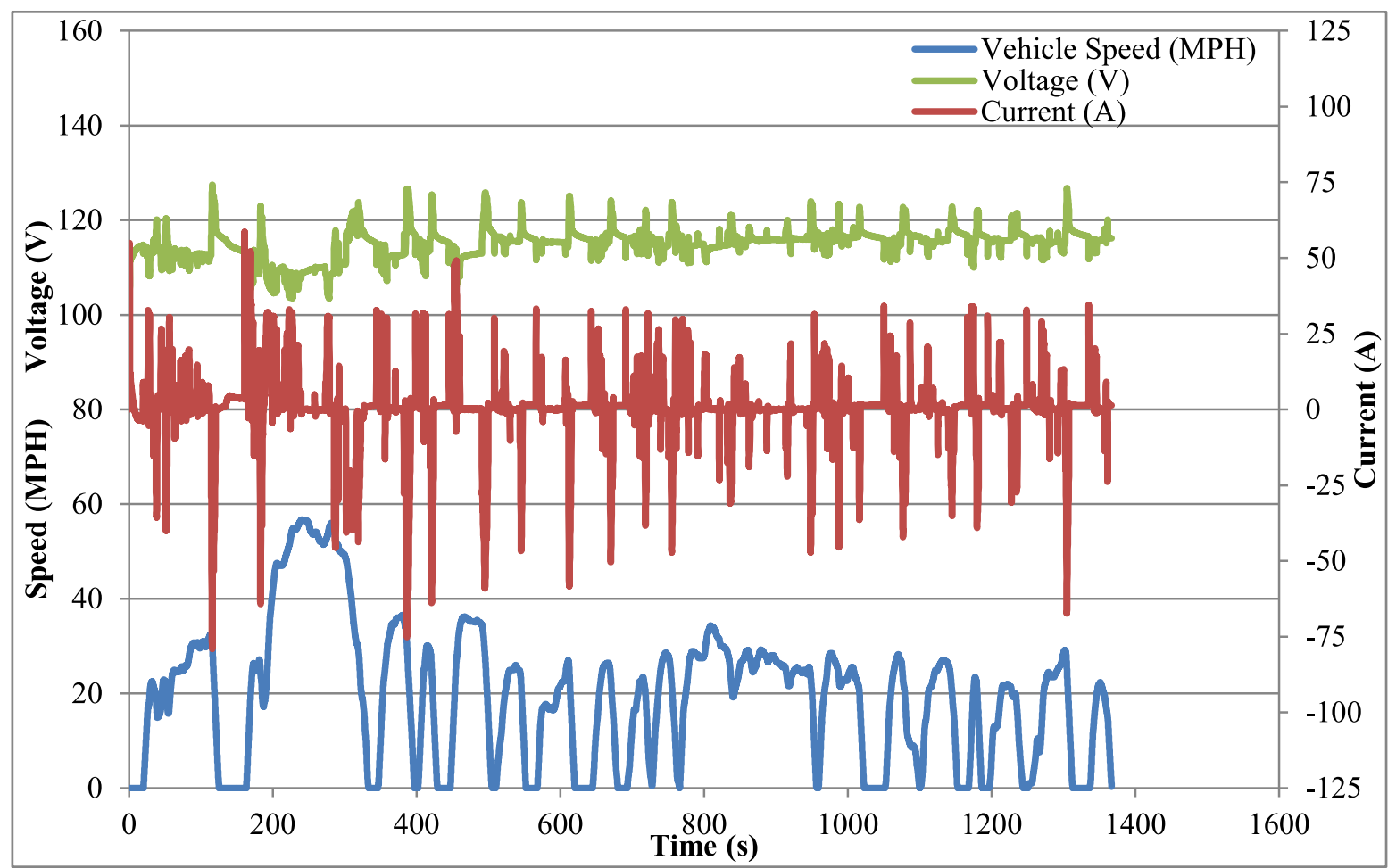

Figure 11. Battery pack current, voltage, and vehicle speed for the UDDS cycle 


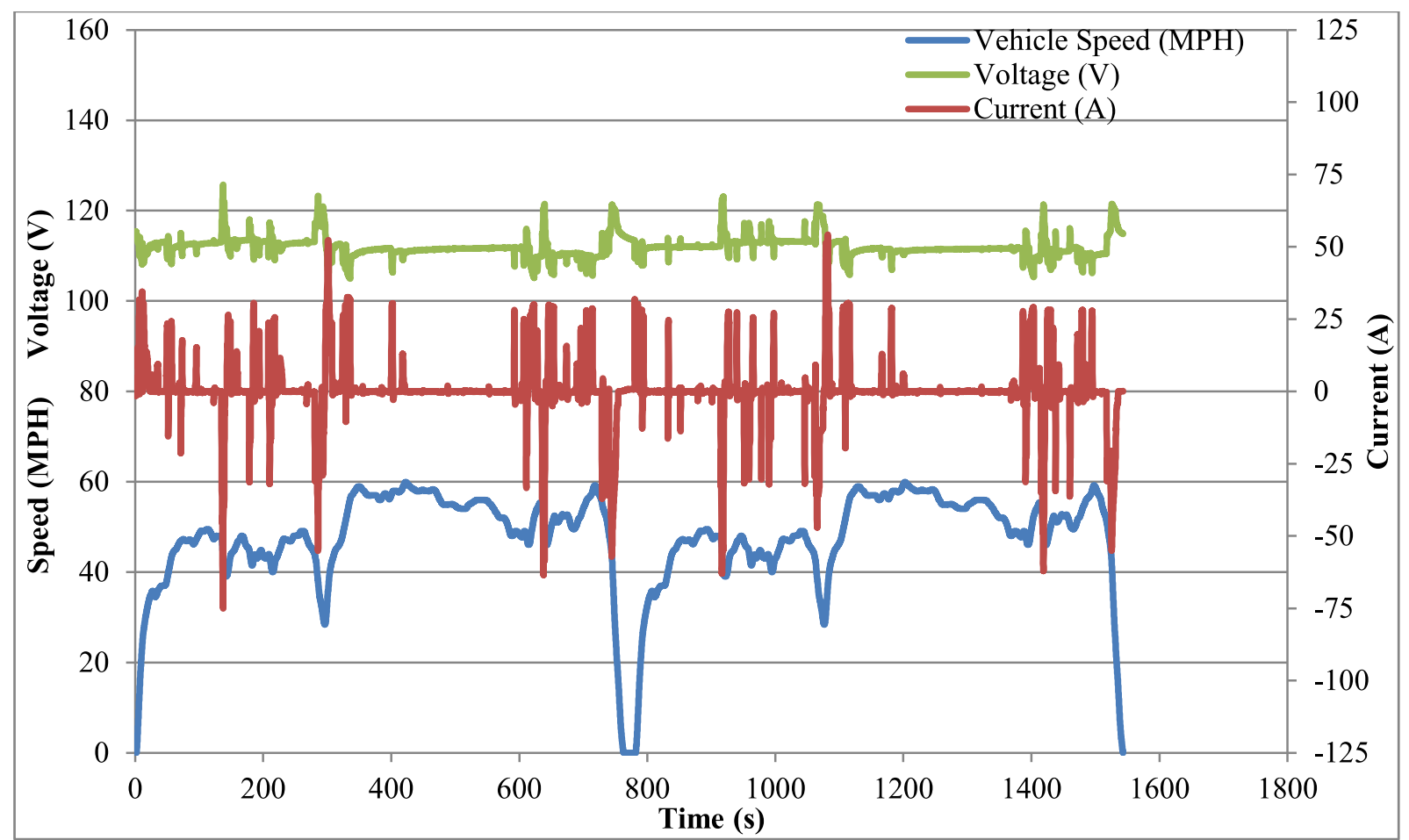

Figure 12. Battery pack current, voltage, and vehicle speed for two back-to-back HWFET cycles

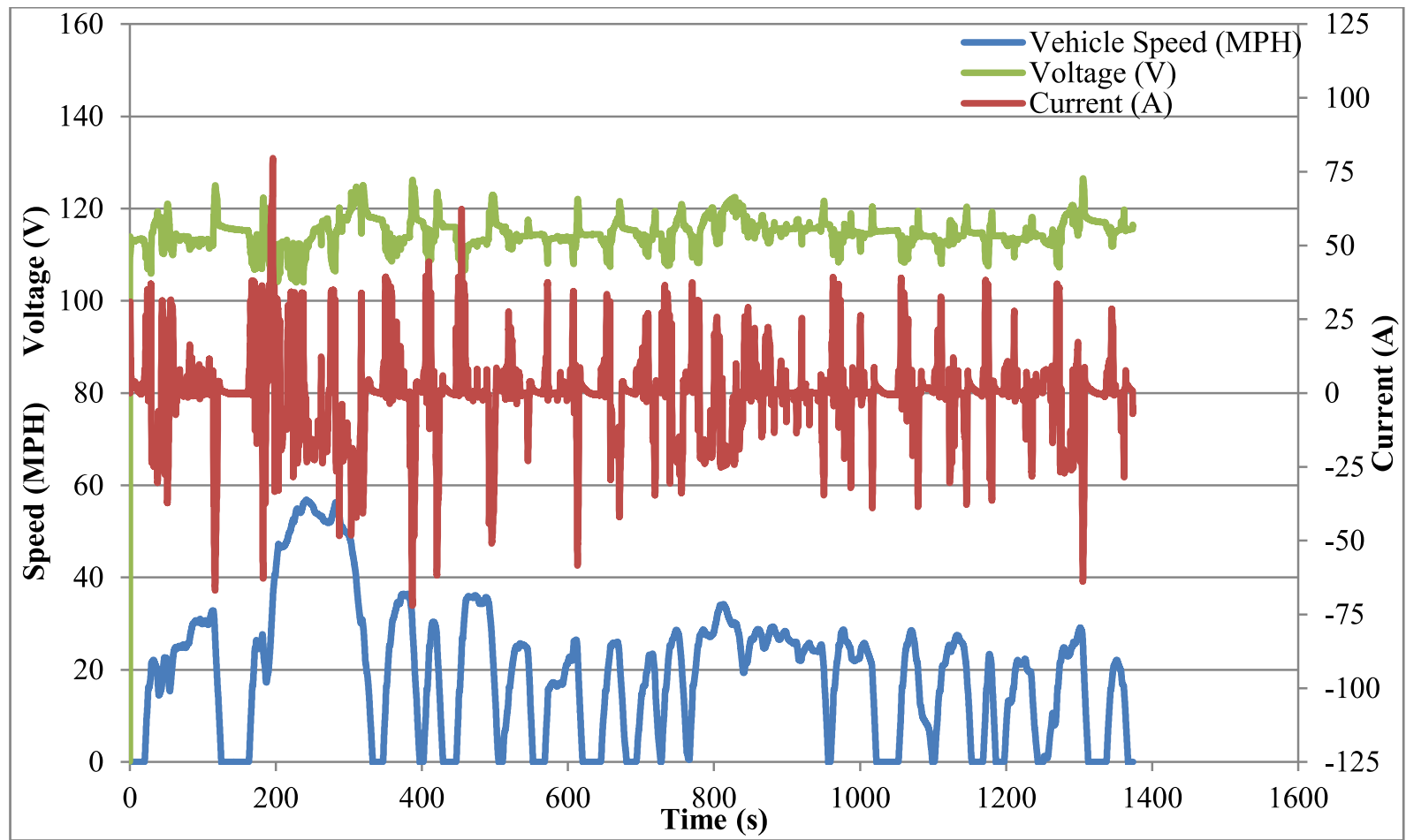

Figure 13. Battery pack current, voltage, and vehicle speed for a UDDS cycle with the elevated ambient temperature of $95^{\circ} \mathrm{F}$ and simulated solar load of $850 \mathrm{~W} / \mathrm{m}^{2}$ 


\subsection{On-Road Test Results}

On-road fuel economy for the vehicle was recorded while the vehicle was operating in a fleet ${ }^{5}$ with approximately $35 \%$ city $^{6}$ and $65 \%$ highway routes. Figure 14 presents the combined monthly fuel economy and cumulative fuel economy for the CR-Z HEV 4466 that underwent on-road fleet testing. The monthly fuel economy is derived from the amount of fuel consumed, based on fleet fueling records, and the distance traveled, (based on vehicle odometer readings) for each vehicle within that month. The cumulative fuel economy is a running total of each month's fuel consumption and distance traveled. The ending cumulative fuel economy over the course of the fleet testing was $36.8 \mathrm{mpg}$. While the vehicle fuel economy cannot be directly correlated to operation of the battery pack with only these data, the vehicle fuel economy in Figure 14 is relatively steady over the entirety of testing.

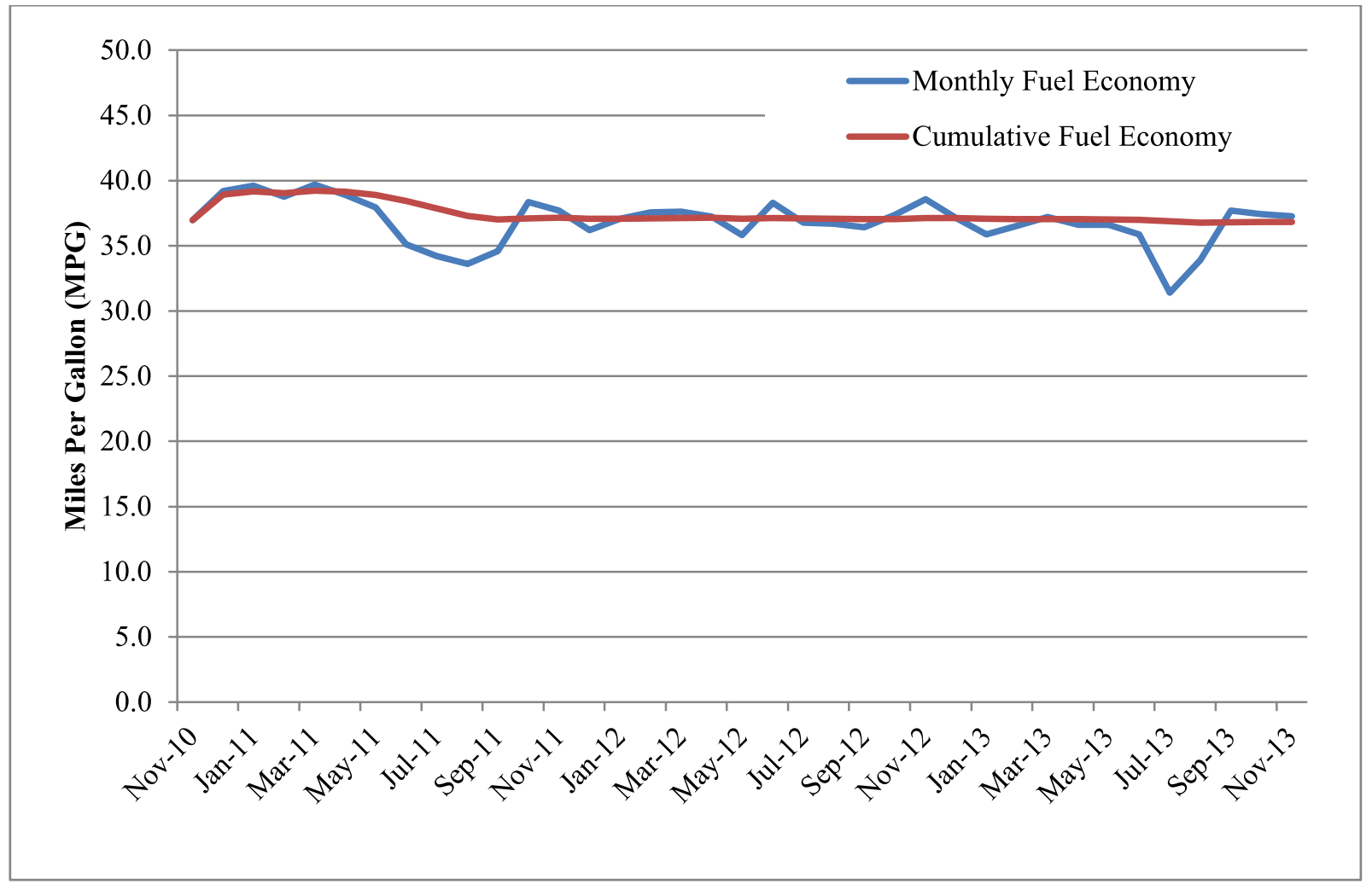

Figure 14. Monthly and cumulative fuel economy

\section{SUMMARY}

The Honda CR-Z 4466 experienced a 12\% decrease in battery capacity and stayed below DOE targets for all aspects of the HPPC test over the duration of 156,271 miles of fleet testing.

5 On-road fleet testing is performed by Intertek (in conjuncture with EZ-Messenger courier services). The vehicles are driven a combination of city and highway routes by several different drivers to expedite the mileage accumulation required to reach EOT.

6 City routes are determined as trips with an average speed less than $42 \mathrm{mph}$. 


\section{Appendix A \\ Vehicle Specifications and Test Results Summary}

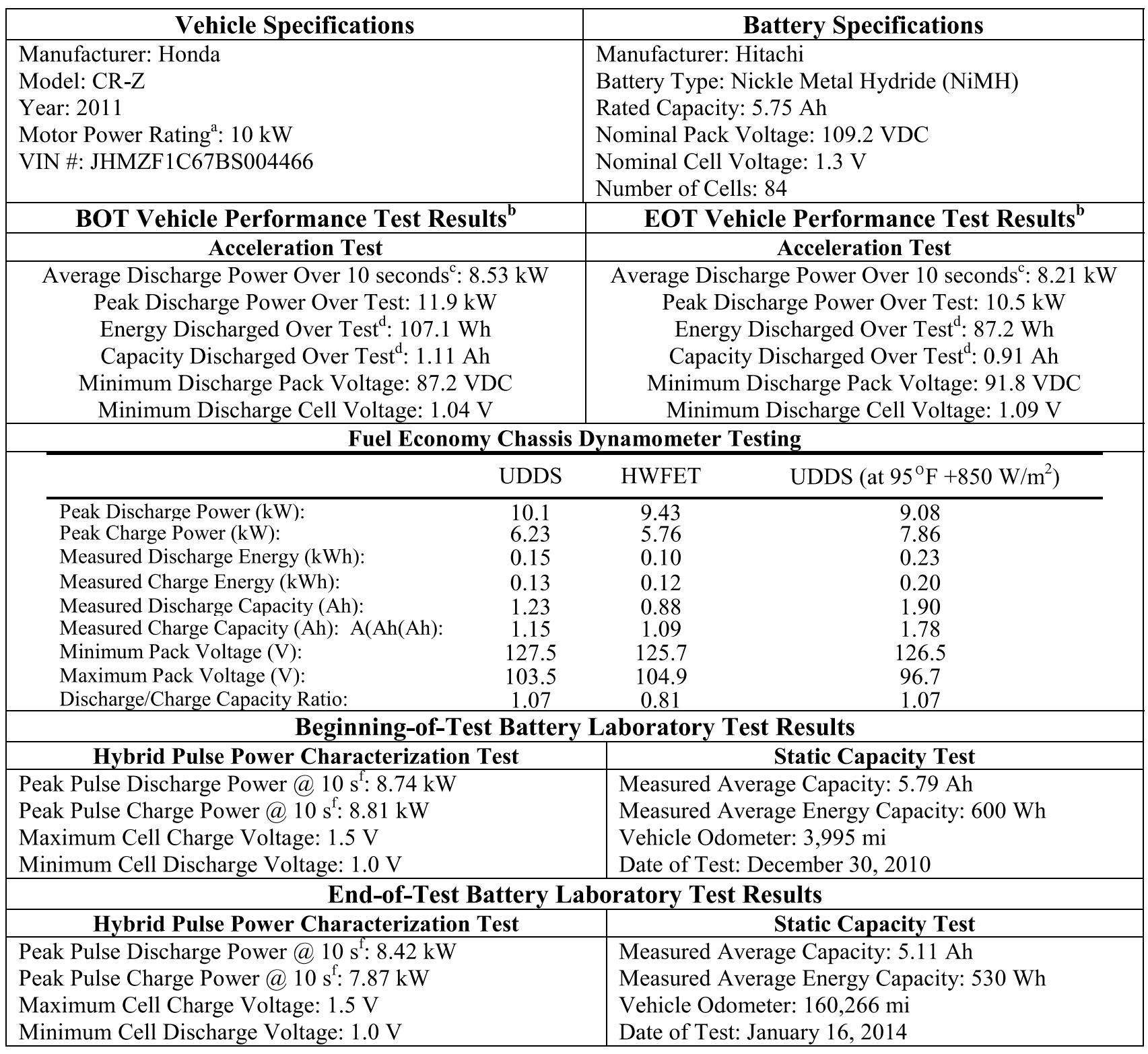


